\title{
PROMOTION OF TRADE AND INVESTMENTS BETWEEN CHINA AND INDIA: The CASE OF SOUTHWEST CHINA AND EAST AND NORTHEAST INDIA
}

\author{
BISWA N. BHATTACHARYAY \\ PRABIR DE
}

CESIFO WORKING PAPER No. 1508

CATEgory 7: TRAde Policy

JULY 2005

An electronic version of the paper may be downloaded

- from the SSRN website:

www.SSRN.com

- from the CESifo website:

www.CESifo.de 


\title{
PROMOTION OF TRADE AND INVESTMENTS BETWEEN CHINA AND INDIA: THE CASE OF SOUTHWEST CHINA AND EAST AND NORTHEAST INDIA
}

\begin{abstract}
Open regionalism and integration between the world's two largest developing countries - the People's Republic of China (China) and India - in trade, investments and infrastructure development can foster outward-oriented development and economic and social benefits that could result in poverty reduction. In view of the increasing trend toward regional integration, particularly the expanded European Union and North American integration, the opportunity costs of not moving toward greater economic integration between China and India involving common neighbouring countries could be increasing. This paper discusses the above subject in the context of possible areas of China - India economic cooperation and integration in the Eastern and Northeastern region of India and Southwestern provinces of China, including neighbouring countries like Bangladesh, Bhutan, Myanmar, and Nepal.
\end{abstract}

JEL Code: F1, F2, Q1, Q4, R4.

Keywords: India, China, economic cooperation and integration, trade, investment and infrastructure development.

Biswa N. Bhattacharyay
Principal Reform Coordination Specialist
Office of the President
Asian Development Bank
P.O. Box 789, 6 ADB Avenue
Mandaluyong City
Metro Manila 0401
Philippines
bbhattacharyay@adb.org

An earlier version of the paper was written for the "International Symposium on Trade and Development between Tibet Autonomous Region and Its Neighbouring Countries", organised by the China International Centre for Economic and Technical Exchanges, Ministry of Commerce, Government of People's Republic of China, and the United Nations Development Programme, held at Lhasa, Tibet during 21-23 September 2004. The views expressed in this article are those of the authors and they do not represent the policy or views of the Asian Development Bank or Research and Information System for Developing Countries. 


\section{Promotion of Trade and Investments between China and India: Regional Challenges \\ Biswa N. Bhattacharyay and Prabir De}

\section{Background}

The economic relations between the People's Republic of China (henceforth China) and India and the relative spheres of activities are the most progressing issues of internal relations. With the ongoing economic reform program and market liberalization process, which is gradually being extended to most sectors of the economy, the entire scope and responsibilities of two governments have increased and new vistas for economic opportunities have been opened between the two countries.

China and India have strong historical and cultural links, and they share many similarities. They are two of the world's most populous countries, sharing between them over a third of the world's population. They represent century old civilizations and unique history. After pursuing inwardoriented policies in the early years of their development, China (since 1979) and India (since 1991) have increasingly deepened their economic integration with rest of the world over the past two decades. While China has emerged as one of the world's fastest growing economies, India's economy with a robust annual growth rate of over $8 \%$ in last two consecutive years, is also showing a healthy growth momentum. China and India have not only attempted to deepen their economic relations within Asia but also between themselves. Bilateral trade and investment links between the two countries have grown rapidly over the past few years, suggesting the presence of complementarities and unexploited potentials.

Substantial complementarities characterize the economic structures of China and India. While China has emerged as the manufacturing hub of the world, India's strengths in knowledge-based services and manufacturing are gaining recognition. The complementary strengths of the two economies can be exploited for mutual benefit. Opportunities for fruitful cooperation exist in many areas such as manufacturing, services, and investment. Their geographical proximity and large-sized economies would facilitate exploitation of these synergies. They can also pool resources for improving their competitiveness in third neighbouring countries, particularly, Bangladesh, Bhutan, Myanmar, and Nepal. They can fruitfully share their development experiences and cooperate in several areas, especially in the critical area of energy security. 
China-India economic cooperation has the potential to benefit over a third of humanity. ChinaIndia cooperation could also be instrumental in building closer border trade between them to enable both to regain their place in the world economy as they had before the $18^{\text {th }}$ century. This would also facilitate poverty reduction in these countries, particularly in border areas where there is relatively high incidence of poverty.

Economic cooperation between China and India has been deepening in recent years. They have decided to focus on economic issues instead of political and security matters. They respect each other's success and work for common interests, particularly in improving the quality of life of their citizens. Benefits of closer economic cooperation have been reflected in rising bilateral trade between the two countries. China and India officially resumed trade in 1978. Both countries signed a Trade Agreement (Most Favoured Nation Agreement) in 1984. China-India bilateral trade has grown rapidly in the last decade from US\$ 338.54 million in 1992 to US\$ 7.6 billion in 2003, up by $53.6 \%$ over 2002. In the past few years, China-India bilateral trade exhibited a sustained pattern of growth. In view of the trade complementarities based on comparative and competitive advantages, the potential for further enhancing trade is significant. The rapid growth trend continued in 2004. Between 1995 and 2003, the bilateral trade between China and India maintained a relatively robust annual growth rate of $26.4 \%$, higher than the average growth rate of the total foreign trade volume in the same period for both China and India. In 2003, the bilateral trade volume between China and India stood at US\$ 7.6 billion, of which China’s export amounted to US\$ 3.34 billion and India’s export amounted to US\$ 4.25 billion. In 2004, India became the $11^{\text {th }}$ largest trade partner of China and the largest in South Asia. Bilateral trade between India and China reached a total of US\$ 13.6 billion, representing an increase of 79.1\% over the corresponding period last year (Government of India, 2005). Despite this rapid growth, India's share of China's imports in 2003 is just 1.03\%, while China's share in India's imports is just under $5 \%$. This suggests that the potential for trade expansion is very large. Each side is now focused to take advantage of rising opportunities for mutual gains, rather than to compete with each other.

In June 2003, China and India signed the Declaration on Principles for Relations and Comprehensive Cooperation and agreed to hold the ministerial meeting of the Joint Economic Group (JEG). A compact Joint Study Group (JSG) composed of government officials and economists was organized to examine the potential complementarities between two countries to enhance trade and economic cooperation. The JSG is aimed to develop a program for the 
development of China-India trade and economic cooperation for the next five years. The JSG's report entitled "Report of the India-China Joint Study Group on Comprehensive Trade and Economic Cooperation” was submitted in April 2005 during the visit of Chinese Premier in India.

The emergence of China and India as major economic forces in the world and their greater openness are the key factors for pushing closer integration between these two countries. Because of the complementarities between China and India, particularly between Eastern and Northeastern India (ENEI) and Southwestern China (SWC), properly paced regional integration can help boost both the quantity and quality of economic growth, bringing benefits to all participating countries or economies. Cross-border initiatives relating to trade facilitation and investment promotion can be instrumental in generating jobs, increasing subregional gross national product (GNP), improving intra-subregional trade, and deepening the economic fabric.

SWC comprises three provinces (Sichuan, Ghizhou, Yunnan), two autonomous regions (Tibet, Guangxi) and one municipality (Chongqing). ENEI consists of Arunachal Pradesh, Assam, Manipur, Meghalaya, Mizoram, Nagaland, Sikkim, Tripura, and West Bengal. They have about 30 million people (out of a total of about 120 million) living below (those with incomes of less than $\$ 1$ a day) the poverty line (Ray and De, 2003). ${ }^{2}$ This is indeed alarming, because, in the whole of China and India, the number of people living below the poverty line stands at about 400 million (Ray and De, 2004). SWC and ENEI are among the less developed regions of China and India, respectively, but have very rich resource endowments. The forest deposits of the states of Assam, Arunachal Pradesh and West Bengal, the hydrocarbon resources of the States of Assam, and Tripura; and the hydropower potential of Assam and Manipur, can supply an enormous amount of inexpensive energy if developed and used in a cooperative manner. The abundance and variety of forest, livestock, and mineral resources in these regions are remarkable. The huge labour force in these regions with suitable training can be mobilized to maximize the benefits from these natural resources, and in the process, transform the region by removing poverty and paving the way to prosperity. For the people of one of the less developed but potentially most prosperous areas of the world, the first decade of the $21^{\text {st }}$ century begins with new challenges on environmental sustainability, economic productivity, and international competitiveness. The future quality of life and economic prosperity in these regions will depend crucially on how they choose to meet these challenges in a united way. Cross-border infrastructure development in this geographically integrated region is crucial to promote greater trade and investment and

\footnotetext{
${ }^{2}$ The incidence of poverty does not count for Tibet Autonomous Region (TAR).
} 
consequently attain economic prosperity. Developing border trade between SWC and ENEI is crucial for enhancing bilateral trade. The Chinese Government announced preferential investment policies for its Southwestern provinces. India, on the other hand, also focused on developing required infrastructure in its Eastern and Northeastern region to facilitate such border trade.

One of the key instruments for economic development and poverty reduction is regional cooperation and integration. Regional cooperation and integration in trade, investment, and infrastructure development can foster outward-oriented development and economic and social benefits. Open regionalism and integration between two of the world's largest developing countries, China and India, could be a countervailing power to withstand the excesses of economic globalization. With the unsuccessful World Trade Organization (WTO) trade talks in Cancun, there is an increasing trend toward regional integration, such as bilateral and regional preferential trade agreements in Asia and in other regions, particularly the expanded European Union and North American integration, namely, the North American Free Trade Agreement (NAFTA) and Central American Free Trade Agreement (CAFTA). In view of this, the opportunity costs of not moving toward greater economic integration between China and India and among neighbouring countries could be increasing.

This paper discusses the above subject in the context of possible areas of China-India economic cooperation and integration for promotion of trade, investment between SWC and ENEI.

\section{Economic Cooperation between East and Northeast India and Southwest China}

\subsection{Eastern and Northeastern India - Profile and Potential}

While focusing on the strengths and potential business drives in individual Northeastern states, the assets of these states must be seen comprehensively as a whole. About $98 \%$ of this region's borders form India's international boundaries. The region shares borders with China in the north, Bangladesh in the southwest, Bhutan in the northwest and Myanmar in the east. One of the major obstacles to economic integration between SWC and NEI is the low supply and inferior quality of infrastructure facilities. 
Table 1. Demographic Profile of NEI

\begin{tabular}{|l|c|c|c|c|}
\hline \multirow{4}{*}{ States } & \multicolumn{2}{|c|}{ Population } & \multicolumn{2}{c|}{ Area } \\
\cline { 2 - 5 } & $\mathbf{2 0 0 1}$ & $\begin{array}{c}\text { Share in } \\
\text { TIP }^{\mathbf{a}}\end{array}$ & $\mathbf{2 0 0 1}$ & Share in TIA $^{\mathbf{b}}$ \\
\cline { 2 - 5 } & $\mathbf{( m i l l i o n )}$ & $\mathbf{( \% )}$ & $\mathbf{( S q ~ K m )}$ & $\mathbf{( \% )}$ \\
\hline Arunachal Pradesh & 1.09 & 0.11 & 83743 & 2.83 \\
\hline Assam & 26.64 & 2.59 & 78347 & 2.65 \\
\hline Manipur & 2.39 & 0.23 & 22327 & 0.75 \\
\hline Meghalaya & 2.31 & 0.22 & 22388 & 0.76 \\
\hline Mizoram & 0.89 & 0.09 & 21214 & 0.72 \\
\hline Nagaland & 1.99 & 0.19 & 16575 & 0.56 \\
\hline Sikkim & 0.54 & 0.05 & 7096 & 0.24 \\
\hline Tripura & 3.19 & 0.31 & 10497 & 0.35 \\
\hline West Bengal & 80.22 & 7.81 & 88752 & 3.00 \\
\hline NEI 9 & 118.17 & 11.51 & 267196 & 9.03 \\
\hline India & 1027.02 & & 2959697 & \\
\hline States & State GDP Share & Per Capita Income (PCI) & CAGR of PCI \\
\cline { 2 - 5 } & $2000-01$ & $1990-91$ & $2000-01$ & $1990-2000$ \\
\cline { 2 - 5 } & $(\%)$ & $($ Rs.) & (Rs.) & $(\%)$ \\
\hline Arunachal Pradesh & 0.09 & 5231 & 14587 & 16.26 \\
\hline Assam & 1.58 & 4432 & 10198 & 11.83 \\
\hline Manipur & 0.17 & 3912 & 12823 & 20.71 \\
\hline Meghalaya & 0.19 & 4944 & 13114 & 15.02 \\
\hline Mizoram & 0.08 & 4856 & 14909 & 18.82 \\
\hline Nagaland & 0.16 & 5893 & 12594 & 10.34 \\
\hline Sikkim & 0.05 & 5213 & 15550 & 18.03 \\
\hline Tripura & 0.27 & 4240 & 14348 & 21.67 \\
\hline West Bengal & 7.54 & 5072 & 16072 & 19.72 \\
\hline NEI 9 & 10.13 & 4866 & 13799 & 16.69 \\
\hline India & & 5365 & 16707 & 19.22 \\
\hline Share & & & \\
\hline
\end{tabular}

a. Share in total Indian population (TIP).

b. Share in total Indian area (TIA).

c. Share of each State's net state domestic product in Indian net gross domestic product, considered in current price (new series).d. Taken at current price (new series).

Source: Economic Survey, 2002-2003, Government of India.

The states of India's Northeastern region as a whole represent 9\% of India's geographical area and $12 \%$ of India's total population (Table 2). Although none of the Northeastern states has attained higher per capita income than the national average in recent years, a few of them (Manipur and Tripura) have been successful in attaining higher income growth rates, compared with the national average during 1990-2000.

Northeast India has a much lower population density than the rest of the country. Low population density has been reflected in low urbanization in this region. In general, urbanization is generally 
low here, except in Assam, Mizoram, and Nagaland (Table 3). This may be attributed to the hilly terrain and green biosphere in more than $30 \%$ of the area. While Northeastern India has abundant natural endowments, this region has been suffering from lack of access to the international market due to lack of physical infrastructure networks. In terms of availability of good quality rail and road networks, this region is still far below the national average, and so are its other physical infrastructural facilities (Table 2). Despite these, Northeastern India has witnessed better penetration of social infrastructure.

Table 2. Economic Profile of NEI*

\begin{tabular}{|l|l|c|c|}
\hline \multicolumn{1}{|c|}{ Particulars $^{\mathrm{b}}$} & \multicolumn{1}{c|}{ Unit } & NE9 & India \\
\hline Area & Share in India (\%) & 9 & \\
\hline Population (2001) & Share in India (\%) & 12 & \\
\hline Population Density (2001) & Per sq. km. & 442 & 347 \\
\hline Literacy Rate (2001) & $(\%)$ & 63 & 65 \\
\hline PCE (1998-99) & Kwh & 112 & 290 \\
\hline NSDP in 1970-71 & Share in India (\%) & 10 & \\
\hline NSDP in 1999-2000 & Share in India (\%) & 10 & \\
\hline PCI in 1970-71 & US \$ (at current price) & 89 & 320 \\
\hline PCI in 1999-2000 & US \$ (at current price) & 300 & 363 \\
\hline Railway Density (1998-99) & Km/'000 sq. km & 9.16 & 19.25 \\
\hline Road Density (1998-99) & Km/'000 sq. km & 583.78 & 862.60 \\
\hline Telephone Mainlines (1997-98) & Per 1000 population & 1.96 & 3.88 \\
\hline Seaport Traffic (2002-2003) ${ }^{\mathrm{f}}$ & Million ton & 40 & 360 \\
\hline Landport Traffic (2000-2001) & Million ton & 1.96 & 66 \\
\hline FDI (1991-2002) & US \$ billion & 12 & 45 \\
\hline
\end{tabular}

a. Arunachal Pradesh, Assam, Manipur, Mizoram, Maghalaya, Nagaland, Sikkim, Tripura and West Bengal.

b. Considers average data of nine NEs.

c. Per capita consumption of electricity.

d. Net state domestic product (new series).

e. Per Capita Income (New Series).

f. Overseas traffic handled by Kolkata and Haldia seaports.

g. Overseas traffic handled by Amingaon and Cossipore ICDs, and border posts like Petropole and Hili.

h. Accumulated data, considers only approved projects.

Sources: Various issues of Economic Survey, Government of India and Profile of States, CMIE. Preliminary Results of 2001 Census, Register of Census Operation, Government of India.

Northeastern India is bountifully endowed with biodiversity, hydro-potential, oil and gas, coal, limestone, and forest wealth. It is ideally suited for a whole range of plantation crops, spices, fruits and vegetables, flowers and herbs, much of which could be processed and exported to neighbouring countries. There is also a huge potential for the development of a viable tourism 
sector. In some sense, the Northeastern states also provide a bridge to Southeast and East Asia (Verghese, 1997).

The region is often thought to be industrially backward. In reality, the tea industry started in 1886 and is still thriving; and the oil refinery, started in 1897, is the oldest in Asia. It is generally believed that the area is geographically isolated, but in reality, it could be a corridor between Southeast Asia and India.

Contrary to the notion that this region has an underdeveloped transport system associated with high transport costs, it has 12 airports, and the Brahmaputra river basin is perennial and cheapest. While it is widely believed that power situation in the region is dismal, it has $38 \%$ of the country's hydropower potential. Moreover, the climate for investment is most favourable owing to an almost negligible pollution, maximum number of incentives, and high percentage of English-speaking population. While this area has a negative image due to insurgency problems, the number of Industrial Entrepreneurs Memorandum (IEM) filed here is higher than the national average. Between 1991 and 2002, the number of IEMs filed in the northeast region was about 300, with a proposed investment figure of about rupees (Rs) 80 billion, and a potential workforce of 45,000. Between December 1999 and January 2003, the number of IEMs rose by 140\%, compared with a $17 \%$ increase at the all-India level. ${ }^{3}$ The region has natural gas reserves of 190 billion cubic meters, coal reserves of 909 million tons, hydro electric potential estimated at 49,000 megawatts (MW), oil reserves of 513 million tons, limestone reserves of 4,933 million tons and a forest cover accounting for $25 \%$ of the country's forest area.

\section{(a) Agro and Food Processing, Horticulture, and Forestry}

Agriculture and forestry are the bedrock on which this region has to be built (Government of India, 1997). The region's economy is primarily agrarian, but it is deficient in food supply, importing grain, oilseeds, sugar, meat, fish and eggs, and other supplies, from distant parts of the country. The region's economy can generate a surplus, and the challenge is to ensure that it realizes its true farm potential.

\footnotetext{
${ }^{3}$ Industries already set up in the region include Godrej Sara Lee, Emami, Jyoti Laboratory, Dharampal Satyapal, Kothari Industries, Hindustan Lever, Ozone Pharmaceutical, Ozone Ayurved Products, Guru Detergents and Chemicals, Shyam Century Ferrous, RCL Cement, Barak Vally Cement, Pancharatna Cement, S M Coke, Pepsi, Composite Jute Mill, Jericho Detergent. DSS Infotech, and Lafrage. Some of the prominent projects under implementation in the region are H M Cement, Sai Megha Alloys, Smithkline Beecham, and LG Electronics.
} 
Northeastern states have vast possibilities for growing a range of fruit and vegetables, tuber crops, tapioca, and spices. Mizoram, for example, is well placed to produce passion fruit. Scope for enhanced productivity exists in the cases of citrus, pineapple, banana, and other varieties through tissue culture and the development of breeder seed farms. The hills can exploit niche markets and provide off-season fruit and vegetables to the plains, including Bangladesh and China. Other plantation and spice crops like ginger, turmeric, coffee, cashew, large cardamom, pepper, jackfruit, lemon grass, citronella, and a host of very valuable herbs and medicinal plants, orchids and a whole range of flowers can be developed. The region is the largest producer of tea in the country, with Assam as the leading tea producer supplying $50 \%$ of the country's tea output, followed by Tripura, which is the fifth largest tea producer in the country. Arunachal Pradesh also produces tea, which closely resembles the world-famous Darjeeling tea of West Bengal. The lone tea unit here has been running profitably for some years now. This potential could indeed be tapped. Sikkim produces $80 \%$ of India's large cardamom which enjoys high-value export market in the Middle East. India is the second largest producer of fruits in the world. Of the 388 million tons of fruit produced worldwide, $8.5 \%$ are grown in Indian orchards. The paradox is that its share in the global export market is not even $0.1 \%$. The Government of India has, therefore, identified both fresh fruits and finished products as focus areas. The national target is to capture at least $1 \%$ share of the global trade. Nagaland has immense potential for horticulture because of varying soil and agro-climatic conditions. The present horticulture crops of various fruits cover an area of about 43,000 hectares with an annual production of about 5,000,000 tons. However, with proper planning and investment, the cultivated area under horticultural crops and production can easily be quadrupled.

The food products sector accounts for a bulk of industrial production in Assam. Although the contribution of this sector to the total output of the country's manufacturing sector is very minute, the importance of food products in the state's economy cannot be overlooked. In fact, there is considerable scope for the establishment of large- and medium-scale industries in this sector. In Nagaland, food and food products account for $11 \%$ of the total output value of the state. A fruitprocessing unit is proposed to be set up in Mizoram. Financial assistance of about Rs 18 million has been extended for various projects in the Northeast and Sikkim during 2001-2002 by India's Ministry of Food Processing. According to a report prepared by the North Eastern Development Finance Corporation (NEDFI), the thrust areas identified in the agro-processing sector include canned or bottled products, packaged products, frozen products, dehydrated products, oleoresins, 
meat, milk, poultry, cereal based products, edible oil, fodder, jute and mesta, essential oils and fragrances and plantation crops like tea, jute, rubber and coffee.

Wood and wood-based industries comprise the main industrial segment of Nagaland. It accounts for the bulk of manufacturing in Nagaland. Meghalaya is dependent on wood and wood-based industries to a large extent. Most of the manufacturing units in Arunachal Pradesh are forest based, and their main raw material is wood. The quality of veneer in Arunachal Pradesh is comparable with the best in the world. Small industries of Tripura are based on forest resources like cane and plywood. The bamboo and cane products of Tripura are exquisitely crafted, and are highly acclaimed both in India and overseas. Sikkim has a unique biodiversity. The composition ranges from tropical dry deciduous forests with Sal and its associates in the valleys of Teesta and Rangit to the alpine scrub and grasslands in high altitudes. During the last two decades, the Forest Department has laid emphasis on development of fodder and fuel wood in the agriculture fallow lands of villages, giving priority to plantations of broom grass for fodder and for economic upliftment of the villagers.

Northeast India harvests about 8 million tons of bamboo, which is about 54\% of the country's share. The bamboo sector is currently experiencing a big expansion in China to meet the demand of both its huge internal market and increasing exports. Average yearly household income from bamboo shoots in China, in villages specializing in the production of bamboo shoots, amounts to US\$2,500, with some villages soaring above US\$10,000. Given the right initiative, this region could continue effectively toward fulfilling the worldwide demand for bamboo.

Sericulture is another activity which is popular in the region. Excellent quality silk of eri and muga variety are grown in Assam. In fact, the cultivation of bi-voltine variety of silk should be encouraged so that the quality of silk that is produced can compete with the best silks in the world. There are immense opportunities for setting up modern silk processing plants in this region. Manipur is set to worm its way up on the silk route. The state was once a key staging post on the ancient silk route. Traders carried silk from China’s Yunnan Province through Myanmar, across India and finally to Afghanistan, where they joined the main silk road. Manipur is poised to spin this tradition into business once again. Japan's Overseas Economic Cooperation Fund (OECF) has loaned Manipur US\$32.77 million in the first phase of a project to revitalize its silk industry. This project aims to increase Manipur's annual silk output to 328 tons from 202 tons by 2002- 
2003. Sericulture accounted for $1.48 \%$ of the State's real GDP. That proportion is likely to rise sharply once the industry takes hold.

\section{(b) Energy}

Energy is a crucial element for the sustained economic growth of this subregion. Marked by high mountains and major rivers, the region needs to build power-generation capacities as well as transmission grid in an optimal manner to serve the entire subregion. The development of costeffective and environment friendly hydropower projects is crucial for long-term development of the electricity market in this region.

The region has all the resources to become the future powerhouse of India. The potential developed in the Northeastern states is only $253 \mathrm{MW}$, which is about $0.8 \%$ of the total available potential. More than two thirds of India's total hydropower potential (84,000 MW) exists in the Northeastern region.

The region houses the largest perennial water system in the country. The state of Arunachal Pradesh is known as the powerhouse of northeast India. The untapped hydropower potential, is estimated at 49,000 MW, of which only 2,365 MW (just about $0.05 \%$ of the total potential) has been harnessed. Some 15 projects with a total installed capacity of $50 \mathrm{MW}$ are being set up. For ecological reasons, this state encourages power-generation projects based on "run-of-the river system” and mini- and micro-hydropower projects.

With 8,000 MW of hydro-electric potential, ample opportunities exist for private sector investments in the energy sector of Sikkim. Meghalaya is one of the few states in the country with a surplus power generation capacity. The total installed capacity of this state is $185 \mathrm{MW}$. Meghalaya has a power potential of about 3,000 MW. The excess power generated in this state is presently being sold to the neighboring states. In the case of Nagaland, there are prospects for future power generation through (i) Shilloi hydroelectric project (6 MW) and (ii) Tizu-Zungki basin (2000 MW). The current power generation in Nagaland (micro-hydel) is about 2.3 MW, and the projected generation (underway) is about $30 \mathrm{MW}$.

\section{(c) Coal}


Mineral reserves in Arunachal Pradesh are reported as follows: coal 84.23 million tons, dolomite 154.13 million tons, limestone 409.35 million tones, and semi limestone 45.82 million tons. In Meghalaya, the coal reserves are concentrated in the West Darrangiri area of the Garo hills possessing about 127 million tons.

\section{(d) Natural Oil and Gas}

Assam accounts for nearly 50\% of onshore crude oil production in the country. It has over 1.3 billion tons of proven crude oil and 156 billion cubic meters of natural gas reserves. Tripura has vast reserves of natural gas in non-associate form. The gas is of high quality, with methane contents of about $97 \%$ and without any presence of $\mathrm{H}_{2} \mathrm{~S}$, or sulphur and other impurities. The Oil and Natural Gas Commission (ONGC), an Indian public sector firm has been actively engaged in exploration activities in this state since 1972. The availability of superior quality natural gas at concessional price offers a great opportunity to prospective investors, to set up gas-based industrial units using natural gas as feedstock. The prospects of crude oil availability in Arunachal Pradesh have brightened after a few successful discoveries of new areas as potential reservoirs for crude oil. The oil reserves may be more than 30 million tons in Arunachal Pradesh.

\section{(e) Tourism}

Opening borders between Southwest China and Northeast India will enhance tourism activities. Countries could jointly develop new tourism products, marketing strategies, and invest in tourism infrastructure development. Northeast India is a scenic mountainous area, with brooks, pools, waterfalls, woods, and fruit-bearing trees. The area has also historical sites, pilgrimages, temples, handicrafts and wildlife.

Bordering on China and Bangladesh, this region has absorbed many waves of migrations. Here Indo-Aryan, Tibeto-Burmese, Chinese, and Mon-Khmer races have mingled with the aborigines to create colorful communities and different political systems amid the fertile Brahmaputra and Surma valleys, the resource-rich Eastern Himalayas, and their foot-hills. All the eight northeastern states offer varying attractions. Their language, customs, traditions, history, folklore, festivals, and handicrafts differ as much as their people. Since 1995, the restricted areas permit requirement has been done away with for most of the northeast states. The Japanese were the 
main foreign visitors to Manipur. They came to pray at the graves of their forefathers, who perished in World War II.

The Government has permitted tourism in selected areas since the early 1980s, recognizing northeast India's tremendous potential for adventure tourism. Sustained economic development and political stability are encouraging private investors to join the various state tourism corporations in creating the hotel and transport infrastructure essential for catering to growing domestic and international traffic. Twelve airports, helipads, and private domestic airlines have made these states more accessible.

The whole State of Sikkim is endowed with rich natural resources. With altitudes ranging from 300 to over 5000 meters, Sikkim is covered with tropical forests, temperate forests, alpine meadows, and snow-capped peaks. The tourism potential of this state is still under-exploited. An excellent opportunity exists to exploit the tourism potential in a sustainable manner without damage to the environment.

The most exciting bird habitat in Asia is found in the rainforests of the Himalayan foothills of eastern Arunchal Pradesh and the magnificent wetlands of the Brahmaputra River Valley in Assam. The extreme Northeastern part of India is one of the richest bird habitat areas on the earth. The tourism potential of the region is considerable, particularly in promoting adventure tourism in Arunachal Pradesh, which has quite a few fast-flowing rivers and hilly terrain. River rafting and other water sports and trekking can be promoted among foreign and domestic tourists in Arunachal Pradesh. The tourism potential of Meghalaya is also significant. Shillong, the State's capital, is already an important tourist destination. Each of the states such as Sikkim, Nagaland, Manipur, Mizoram and Tripura and their rich culture, picturesque locales, rare flora and fauna, and historical monuments make the region an attractive tourist destination.

\section{(f) Exports}

The products those are currently exported from the region are tea, cotton, jute, pineapple, medicinal herbs, broomstick, tejpatta, orchids, limestone, coal, tea processing machinery, handloom textile, woollen carpets, cane and bamboo products. Presently, Northeast India's total exports and imports are Rs. 4349.60 million and 332.80 million respectively (Table 3). Noticeable change is the sharp increase in Northeast India’s exports to Myanmar. 
Table 3. Exports from Northeast India

\begin{tabular}{|l|l|c|c|c|c|c|c|}
\hline \multirow{2}{*}{ Year } & $\begin{array}{l}\text { Total } \\
\text { Export }\end{array}$ & \multicolumn{9}{|c|}{$\begin{array}{c}\text { Northeast's Export } \\
\text { to }\end{array}$} & $\begin{array}{l}\text { Total } \\
\text { Import }\end{array}$ & \multicolumn{2}{|c|}{$\begin{array}{l}\text { Northeast's Import } \\
\text { from }\end{array}$} \\
\cline { 2 - 8 } & & Bangladesh & Myanmar & $\begin{array}{c}\text { Other } \\
\text { Countries }\end{array}$ & & Bangladesh & Myanmar \\
\cline { 2 - 8 } & \multicolumn{7}{|c|}{ (Rs. Million) } \\
\hline $1999-00$ & 3958.90 & 1698.10 & 33.10 & 2204.30 & 187.50 & 94.40 & 66.80 \\
\hline $2001-02$ & 3799.50 & 1861.30 & 12.30 & 1971.10 & 159.40 & 55.00 & 75.90 \\
\hline $2003-04$ & 4349.60 & NA & 94.10 & NA & 332.80 & NA & 131.80 \\
\hline
\end{tabular}

NA means data not available

Source: Indian Custom, Shillong, Meghalaya

It may thus be concluded that this region enjoys the following special advantages over other regions of India.

(i) A market of 400 million people is emerging, including neighboring countries like Bangladesh, Bhutan, China, Myanmar, and Nepal. ${ }^{4}$

(ii) The region has the potential of developing into India's powerhouse. The area is a vibrant source of energy, rich in oil, natural gas, coal, and limestone. India's largest perennial water system in the river Brahmaputra and its tributaries could be tapped for energy, irrigation and transportation.

(iii) The fertile soil around the Brahmaputra Valley is a storehouse of horticultural products, plantation crops, vegetables, spices, rare herbs, and medicinal plants.

(iv) Unlimited tourism opportunities exist, considering rare flora and fauna, natural scenic beauty, unique performing arts, varied cuisine, and textiles.

(v) Locational advantages make this region attractive to foreign investment. It has unique proximity to other countries in South Asia and Southeast Asia regions. Therefore, this region can emerge as a strategic base for foreign/domestic investors to tap the world's largest market - South Asian Association of Regional Cooperation (SAARC), Bay of Bengal Initiative for Multi-sectoral Technical and Economic Cooperation (BIMST-EC), and the Association of Southeast Asian Nations (ASEAN).

\footnotetext{
${ }^{4}$ India is already committed to South Asia SEC subregional economic cooperation program of Asian Development Bank which involves Bangladesh, Bhutan, India (eastern states), and Nepal. This program envisages subregional cooperation in the areas of transportation and communication, energy and power, tourism, environment, trade, investment and private sector cooperation.
} 
(vi) Already, a border point between Myanmar and the northeast has been opened at Moreh (Manipur) with a possibility of a second border point being opened at Champhai. Besides, Assam's internal waterway network connects it to Bangladesh, giving it access to the ports of Chittagong (Bangladesh), Calcutta and Haldia (West Bengal).

(vii) Industrial growth centers have already been converted into total tax free zones for the next 10 years.

(viii) Government incentives on transport, capital investment, and interest on the working capital are available for industries in the region.

Table 4. Economic Profile of Southwest China

\begin{tabular}{|c|c|c|c|}
\hline Particulars & Unit & SW China & China \\
\hline Population distribution (1999) & $\%$ & 19.50 & \\
\hline Share in area (1999) & $\%$ & 57.30 & \\
\hline Share in country, GDP (2000) & $\%$ & 11.00 & \\
\hline GDP composition (1999) & & & \\
\hline Primary sector & $\%$ & 24.80 & 16.70 \\
\hline Secondary sector & $\%$ & 40.70 & 46.50 \\
\hline of which: Industry & $\%$ & 33.60 & 40.00 \\
\hline Tertiary sector & $\%$ & 34.50 & 36.80 \\
\hline Per capita GDP (2000) & US \$ & 650.00 & $1,250.00$ \\
\hline $\begin{array}{l}\text { Distribution of main crop production (1999) } \\
\text { Cereals } \\
\text { Cotton } \\
\text { Fibres }\end{array}$ & $\begin{array}{l}\% \\
\% \\
\%\end{array}$ & $\begin{array}{c}16.40 \\
2.10 \\
14.40\end{array}$ & \\
\hline $\begin{array}{l}\text { Crop yields (1999) } \\
\text { Rice } \\
\text { Wheat }\end{array}$ & $\begin{array}{l}\mathrm{Kg} / \mathrm{Ha} \\
\mathrm{Kg} / \mathrm{Ha}\end{array}$ & $\begin{array}{l}6,444.00 \\
2,533.00 \\
\end{array}$ & $\begin{array}{l}6,345.00 \\
3,947.00 \\
\end{array}$ \\
\hline $\begin{array}{l}\text { Industrial structure } \\
\text { Share of light industry in industrial production (1999) } \\
\text { Share of mining in the industry of each region (1995) } \\
\text { Share of chemical industry in the manufacturing } \\
\text { industry of each region (1995) } \\
\text { Share of textile industry in the manufacturing industry } \\
\text { of each region (1995) }\end{array}$ & $\begin{array}{l}\% \\
\% \\
\% \\
\% \\
\end{array}$ & $\begin{array}{c}42.50 \\
9.90 \\
\\
8.30 \\
\\
3.60 \\
\end{array}$ & $\begin{array}{r}42.00 \\
12.40 \\
7.70 \\
\\
11.80 \\
\end{array}$ \\
\hline $\begin{array}{l}\text { Degree of integration } \\
\text { Share in total exports (1999) } \\
\text { Share in total manufacturing exports (1997) } \\
\text { Share in total imports (1999) } \\
\text { Openness (1999) } \\
\text { Share in total investments (domestic + foreign) (1999) } \\
\text { Per Capita Trade (2000) }\end{array}$ & $\begin{array}{l}\% \\
\% \\
\% \\
\% \text { of GDP } \\
\% \\
\text { US \$ } \\
\end{array}$ & $\begin{array}{c}2.20 \\
3.10 \\
2.00 \\
3.60 \\
3.50 \\
37 \\
\end{array}$ & 366 \\
\hline $\begin{array}{l}\text { Foreign direct investment (2000) } \\
\text { Total FDI } \\
\text { Per Capita FDI } \\
\text { FDI/GDP }\end{array}$ & $\begin{array}{l}\text { US \$ billion } \\
\text { US \$ } \\
\%\end{array}$ & $\begin{array}{l}1.36 \\
6.00 \\
0.47 \\
\end{array}$ & $\begin{array}{c}40.71 \\
31.00 \\
2.59 \\
\end{array}$ \\
\hline
\end{tabular}


Source: China Statistical Yearbook, 2001 and 2002.

Northeast India is unique in terms of opportunities. It has certain peculiarities and problems, which, if tackled and leveraged in the right perspective, could yield rich dividends. While it is an industrial desert where almost all consumables are imported from outside the region, it is the focal point of trade within a vast area. It is, therefore, essential to evolve a regional approach as opposed to the individual state approach. Northeast India's locational advantage and rich natural resources provide a backdrop to its development as a base for cooperation not only with China but also with neighbouring countries such as Bangladesh, Bhutan, Nepal and Myanmar, and through Myanmar, subregional cooperation can be extended to Cambodia, Lao People's Democratic Republic, Thailand, and Viet Nam.

\subsection{Southwest China: Profile and Potential}

The Southwest region in China may not be able to achieve the economic growth rates of the eastern part of China for a long period. Southwest China consists of three provinces (Sichuan, Ghizhou, and Yunnan), two autonomous region (Guangxi and Tibet) and and one municipality (Chongqing). Southwest China is especially disadvantaged in factor endowment. A fundamental precept of the Government of China's Western Development Strategy is the reduction of disparities among the regions and the prevention of further degradation of the ecological environment. Despite impressive economic growth in the last two decades and the Government's consistent efforts to promote balanced regional development, the entire Southwestern region of China still lags behind in some aspects of social and economic development (see Table 4).

With $19.50 \%$ share in total Chinese population and $57.30 \%$ in total area, the southwest region contributes $11 \%$ of the country's gross domestic product (GDP). Southwest China's economy is primarily agrarian with a moderate presence of an industrial sector. The region has not witnessed any considerable visibility in international trade; the Southwest region contributes only $2.20 \%$ to the country's total exports. Per capita trade of Southwest China is only US\$37, compared with US\$366 for the country as a whole. The region has attracted negligible foreign direct investment (FDI); the per capita FDI in this region is only US\$6, whereas the same for China is US\$31. Naturally, like India's northeast region, the main drawback of the Southwestern region is its geographical isolation. 
The SWC is also rich in natural agricultural and mineral resources. However, potential environment impacts that may be caused by extraction of natural mineral resources in these regions should be taken into consideration during the formulation of projects in this area. More than 70 types of minerals can be found in.the area. Important among them are: chromites (highest deposits in China), lithium (highest deposits in the world), copper (second highest deposits in China), boron (third highest deposits in China), magnetite (third highest deposits in China), barite (third highest deposits in China), arsenic (fourth highest deposits in China), gypsum (second highest deposits in China), pottery clay (fifth highest deposits in China), muscovite (fourth highest deposits in China), and peat (fourth highest deposits in China). Like India's Northeast, Tibet is also rich in plants, water and hydroelectric energy resources. The Yarlung Zangbo river promises 80 million kilowatts $(\mathrm{KW})$ in exploitable energy capacity. Moreover, the hydroelectric capacity of the five tributaries of Yarlung Zangbo, viz., Dogxung Zangbo, Nyang Xu, Lhasa, Ny'ang, and Darlung Zangbo rivers, is assessed at about 90 million KW. Besides hydroelectric resources, Tibet also has huge geothermal energy resources. The Yanbajain geothermal field in Damxung is currently China's largest high temperature steam geothermal field, which is expected to generate $150,000 \mathrm{KW}$ of power a year. ${ }^{5}$ However, not even $1 \%$ of the total geographical area of Tibet is cultivable and only about $6 \%$ is under forest.

In view of China's new strategy, Yunnan and Tibet, being located in the Southwest of China, have been trying to integrate with neighboring countries, particularly with India in South Asia. Vast distances have isolated Tibet and Yunnan from major markets for a long period of time. Yunnan is a neighbour of Guangxi, Guizhou, Sichuang, and Tibet. Because of its common border with Lao PDR, Myanmar and Viet Nam, the Yunnan province is the gateway to Southeast and South Asia. Yunnan is being treated as a passageway for cultural exchange (being the ancient Southern Silk road).

With a total population of 42.9 million, Yunnan's total GDP is about 208 billion yuan, and its per capita income at current price is US\$650. Aggressive economic reform has translated into significant economic growth in the last decade and as a result, the province has been growing at 9\% since 1981, far exceeding the target growth rate of 7\%. Tibet, another landlocked autonomous region of China, is growing at $9 \%$ per annum since 1991, and has also crossed the

\footnotetext{
${ }^{5}$ See www.tibetinfor.com.cn/tibetzt-en/shuju/zirzy.htm
} 
national GDP growth rate. Both the provinces have been successful in improving their per capita income in the last decade. Higher per capita income has been translated into better social conditions during 1990-2000 (Table 5).

Table 5. Economic Profile of Yunnan and Tibet

\begin{tabular}{|c|c|c|c|c|c|}
\hline Particulars & Unit & Yunnan & Tibet & SWC2 & China \\
\hline Population (2000) & Million & 42.90 & 2.60 & 45.50 & 1265.80 \\
\hline Population share (2000) & $\%$ & 3.39 & 0.21 & 3.59 & \\
\hline Area (2000) & Sq km & 394,000 & $1,185,000$ & $1,579,000$ & $9,327,420$ \\
\hline Area share (2000) & $\%$ & 4.22 & 12.70 & 16.93 & \\
\hline Population density (2000) & Pop./sq km & 109.00 & 2.23 & 29.23 & 136.36 \\
\hline Per capita GDP (1980) & RMB/capita & 367.00 & 259.00 & 313.00 & \\
\hline Per capita GDP (1999) & RMB/capita & 4452.00 & 4262.00 & 4357.00 & \\
\hline Growth rate of GDP (1980-90) & $\%$ & 11.80 & 6.40 & 9.10 & \\
\hline Growth rate of GDP (1990-00) & $\%$ & 9.30 & 9.20 & 9.25 & \\
\hline Literacy (1999) & $\%$ & 24.34 & 66.18 & 45.26 & \\
\hline HDI rank (1995) & & 26 & 30 & & \\
\hline Density of Railways (2000) & km/sq km x 100 & 0.49 & 0.00 & 0.25 & 0.61 \\
\hline Density of Roadways (2000) & $\mathrm{km} / \mathrm{sq} \mathrm{km} \times 100$ & 0.52 & 0.05 & 0.29 & 1.60 \\
\hline Total railway networks (1999) & $\mathrm{Km}$ & 3804 & 0.00 & 3804 & \\
\hline Total highways & $\mathrm{Km}$ & 102,405 & 2,2475 & 124,880 & 1,44434 \\
\hline Energy production (1999) & TWh & 29.80 & 0.60 & 30.40 & $1,239.30$ \\
\hline Of which: Coal & Mt & 26.60 & 0.60 & 27.20 & \\
\hline Oil & Mt & 0.00 & 0.00 & 0.00 & \\
\hline Natural gas & GL & 0.10 & 0.00 & 0.10 & \\
\hline Hydropower generation (1999) & TWh/year & 6.90 & 0.20 & 7.10 & 196.6 \\
\hline Hydropwer reserves (1999) & GW & 71.20 & 56.60 & 127.80 & 378.5 \\
\hline \multicolumn{6}{|l|}{ High-Tech Zone (1999) } \\
\hline No. of units & & 80 & & 80 & \\
\hline No. of workers & & 18,955 & & 18,955 & \\
\hline Total income & million yuan & 4,940 & & 4,940 & \\
\hline Exports & US \$ million & 95.40 & & 95.40 & \\
\hline Labor productivity & Yuan / person & 228,980 & & 228,980 & \\
\hline Export per person & US \$ / person & 5,030 & & 5,030 & \\
\hline No of tourists (1998) & million & 28.69 & 0.39 & 29.08 & \\
\hline Tourism income & million yuan & 13,690 & 1,673 & 15,363 & \\
\hline Tourism income & $\%$ of GDP & 7.60 & 18.40 & 26.00 & \\
\hline \multicolumn{6}{|l|}{ International Trade } \\
\hline Share in Country's Total Trade & $\%$ & 0.38 & 0.03 & 0.41 & \\
\hline Share in Country's Total Export & $\%$ & 0.47 & 0.05 & 0.52 & \\
\hline Share in Country's Total Import & $\%$ & 0.28 & 0.01 & 0.29 & \\
\hline Per Capita Trade & US \$ & 42.00 & 50.00 & 46.00 & 366 \\
\hline FDI (2000) & US \$ million & 128.00 & 0.00 & 128 & 40715 \\
\hline
\end{tabular}




\begin{tabular}{|l|l|c|c|c|c|}
\hline Per Capita FDI (2000) & US \$ & 3 & 0.00 & 3 & 31 \\
\hline FDI / GDP (2000) & $\%$ & 0.25 & 0.00 & 0.25 & 2.59 \\
\hline
\end{tabular}

Source: China Statistical Yearbook, 2001 and 2002.

One major source of earnings of Southwest China is tourism. The entire western region of China has many tourism magnets. In the World Heritage List, published by the United Nations Educational, Scientific and Cultural Organization (UNESCO) in 2000, the western region has four attractions listed in the cultural category, and three attractions listed in the natural category, whereas Yunnan and Tibet have one each in this list. $^{7}$ Tibet has a tourism income/GDP ratio above the world average, whereas the same for Yunnan is 7.6\%. About 29 million tourists have visited these Yunnan and Tibet during 2002-2003 and 26\% of state GDP is coming from this sector.

Table 6. Competitive Advantages in Industrial Products of Yunnan and Tibet in 2000

\begin{tabular}{|l|l|l|}
\hline \multicolumn{1}{|c|}{ Category } & \multicolumn{1}{|c|}{ Yunnan } & Tibet \\
\hline Agro-based products & Cigarettes, sugar & \\
\hline Building materials & Timber & Timber \\
\hline Machinery products & Engineering & \\
\hline Chemical products & Sulfuric acid, fertilizer & \\
\hline
\end{tabular}

Source: China Statistical Yearbook, 2000.

Yunnan's plan is to develop the province as a model of dynamic and open "green economy" with a special focus on sustainable natural resource-based industries and service industries, including tourism. The flourishing tourist industry in Yunnan has propelled rapid development of other tertiary sectors of industry, such as catering, transportation, and trade. Since the implementation of the national policy of reform and opening, the various nationalities in Yunnan have strived to developed a flourishing economy by creating some pillar industries, and participated in economic cooperation with local and foreign investors. These efforts greatly strengthened the comprehensive economic power of Yunnan and improved the infrastructure for developing foreign trade. Within a 200-km area around Kunming, the main lines of communication have been modernized, and the preliminary construction of a road network leading to borders and other provinces has been completed. The completion of the Nanning-Kunming and Guangtong-Dali

\footnotetext{
${ }^{7}$ Potala Palace and the Jokhang Temple Monastery in Lhasa in Tibet and Old Town of Lijiang in Yunnan are listed as World Heritage Sites.
} 
railways and the reopening of the Yunnan-Viet Nam Railway have increased the length of rail lines to more than 2,000 km, forming a railway network linking neighbouring and coastal provinces. The civil aviation sector of Yunnan has also made remarkable progress by building and extending nine international airports. The telecommunication facilities of Yunnan have also improved rapidly by means of satellites, optical cables, microwaves, program control, radio wave beepers, mobile phones, and facsimile. The completion of the Manwan hydroelectric power station boosted the energy supply capacity of Yunnan to more than 6.88 million KW.

While a typical factor endowment crisis (the lack of capital and skilled labour) restrains Tibet from having high value-added industrial activities, Yunnan has several major and growing industries such as tobacco, metallurgy, chemicals, machinery, electronics, food, mining, rubber, forestry, pharmaceuticals, biological engineering, hydroelectric power, and floriculture. With its abundant natural resources, strong industrial foundation and good investment climate, Yunnan has been drawing foreign investments from Germany; Hong Kong, China; Japan; Republic of Korea; Singapore; Taipei,China; Thailand; United Kingdom; and United States. According to a recent study conducted by the Asian Development Bank (ADB) (2002), the entire Western region of China enjoys significant competitive advantage in the primary sector. Table 6 lists industry products in which Yunnan and Tibet have competitive advantage. Except for cigarette making, Yunnan and Tibet do not have advantages in highly value-added industries like oil refining, automobile manufacturing, and high-end household appliances.

In this backdrop, Northeast India and Southwest China are symmetric in most of the existing economic dimensions. Although both regions are endowed with mineral resources, particularly hydropower, basic social and physical infrastructure facilities, geographical isolation has kept these two regions in the lower strata of economic development.

Why does India's Northeastern region deserve more developmental attention from the Government of India? This can easily be understood from the Government of China's "look west" policy. ${ }^{8}$ The Western China region contains $29 \%$ of the country's population but

\footnotetext{
${ }^{8}$ In the beginning of 2000, the Chinese Government adopted a long-term strategy for the development of the western region of the country, which it defined as comprising five autonomous regions, six provinces, and one municipality with the status of a province. In 1999, western China region contained $29 \%$ of country's population but accounted for only $16 \%$ of its gross domestic product. Due to disadvantage in factor endowments, the western region of China particularly Southwest China cannot achieve economic growth rates at par with the country's eastern region. Although there are various natural obstacles which are limiting western provinces to march fast, Chinese Government has taken a policy to revive its Southwest
} 
contributes only $16 \%$ of its GDP. Due to disadvantages in factor endowments, the Western region of China particularly, Southwest China, cannot achieve economic growth rates at par with the country's Eastern region. The Government of China is very much interested in developing the country's Western region, which is predominantly a less developed region, compared with its Eastern counterpart. In sharp contrast, India's Northeastern region shares 12\% of India's population but accounts for only $10 \%$ of its GDP. Interestingly, Northeastern India and Southwestern China are not only endowed with a host of similarities but also located in the same geographical plateau. While the Government of China is determined to develop the Southwestern part of the country, India's Northeastern region is likely to attain higher growth, provided the Indian Government adopts a "look east" policy with an intention similar to that of the Chinese Government.

\section{Cross-Border Trade between NEI and SWC}

\subsection{Status of Border Trade in NEI}

Unlike other regions in India, the NEI is bounded by four neighbouring countries. It shares $98 \%$ of its border with them, and only 2\% with rest of India. NEI's border with Bangladesh spans about 2,500 km., with Bhutan 650 km., with China about 1,000 km., and with Myanmar about $1,450 \mathrm{~km}$. The cross-border markets are far nearer in terms of both cost and distance than the mainland's large market places.

Presently, two-way trade flows between the region and the neighbouring Bangladesh, Bhutan, and Myanmar. There are 32 officially recognized land custom stations (LCs) along NEIBangladesh border. Of them only 13 LCs are functioning. Five NEI states are sharing borders with Bangladesh. Assam has four functioning LCS, Meghalaya has six LCs, Tripura has three LCs and West Bengal has 4 LCs. There is no LCs operating in the Mizoram-Bangladesh sector. In the NEI-Bhutan sector, three LCS are operating along the Assam-Bhutan border. In the NEIMyanmar sector, only one LCS is operating in the Manipur-Myanmar border. The flow of trade across NEI and neighboring countries (NCs) may conveniently be classified into three types.

economy by strengthening its competitiveness through closer regional integration with neighbouring countries (Asian Development Bank, 2002). 
Firstly, NEI-Bangladesh trade may be characterized as growth-generating trade. This trade is primarily due to availability of certain natural and agro-forest products in NEI and their nonavailability in Bangladesh. NEI exports to Bangladesh mainly consist of mineral products like coal and limestone, natural products like boulders and stone chips, and a few agro-horticultural products. About $90 \%$ of NEI's exports to Bangladesh consist of mineral products, primarily from Meghalaya. There exists a strong base for NEI-Bangladesh trade because of their mutual complementarities. The resource structure of NEI is complementary to the demand structure of the Bangladesh economy. The demand for mineral products in Bangladesh has led to their commercial exploration in the hills of northeast India, particularly the bordering state of Meghalaya, where large scale deposits of coal (563 million tons) and limestone (4147 million tons) exist. If there been no border trade with Bangladesh, the commercial exploration of these deposits would have been delayed, until their scarcity in the national market would have pushed the price upward to justify high exploration and transportation costs in a peripheral region like Meghalaya.

Although NEI-Bangladesh border trade has accelerated the exploration of local resources, it has not established the triadic linkages between resource mobilization, upgrading of production structure, and trade. What is observed in this case is a dyadic linkage between trade and resource use. However, the triadic linkages are emerging in the case of cement production. Within the last 30 years, the number of cement-producing units in Meghalaya has increased from 1 to 6 within.

Secondly, NEI-Myanmar trade may be characterized primarily as transit trade. A study of the two-way flow of goods showed that goods produced outside the region are mainly exported through the Moreh-Tamu sector (Das, 2000). Similarly, goods of third country origin are mainly imported from Myanmar. NEI-Myanmar trade has not yet been linked with the local resource bases and production structures across the border. Perhaps, because of the competitive character of resource bases across the border the linkages of NEI-Myanmar trade are weak.

Thirdly, NEI-Bhutan trade exhibits altogether different characteristics. This may be characterized as growth-exporting trade. A study (Baruah, 2000) of the commodity composition of NEIs trade reveals that while the imports from Bhutan primarily consist of goods of Bhutanese origin, NEI's exports to Bhutan consist of goods primarily originated from outside the region. The competitive resource structures across NEI-Bhutan border and the limited absorbing capacity of Bhutan's economy do not allow the establishment of any strong dyadic or triadic linkages in the NEI 
economy. NEI-Bhutan's trade generates growth impacts on Bhutan's economy, but the same is very weak in the economy of NEI.

During the last 5 years (1998-1999 to 2002-2003), NEI's average annual export to neighbouring countries amounted to Rs3.96 billion, and its average annual import totalled Rs197.40 million. Thus, NEI has experienced a substantial trade surplus from its trade with neighbouring countries. However, despite having a long border with China, there is no official border trade point along the NEI-Tibet sector. If the trade gap is addressed, increased trade will benefit both regions across the Sino-Indian border.

\subsection{NEI-SWC Border Trade: New Initiative}

Border trade between China and India resumed following the signing of a Memorandum of Understanding during the visit of China”s Premier Li Peng in December 1991. At present, border trade with Tibet in China is conducted through Lipulekh Pass in Uttaranchal (in India) and Shipkila Pass in Himachal Pradesh (in India). Intensified border trade between the countries is urgently needed. In this context, the Prime Minister of India and the Premier of the State Council of China at their summit in June 2003 decided to reopen border trade through Nathu La (in ENEI).

In 2002, China's trade with the seven $\operatorname{SAARC}^{9}$ nations was more than US\$7 billion, whereas India alone accounted US\$5 billion. Cross-border trade with the four South Asian countries is insignificant. Moreover, China and India have had for long no official cross-border trade, though there is a large flow of cross-border Chinese products through a third country.

To expand bilateral trade between China and India, the emphasis should be on cross-border links and the quality of transport infrastructure facilities. The northeastern region of India has no direct transport links with the southwestern region of China. China's western provinces have only two border crossings with South Asia: (i) Kunjirap (in Xinjiang Province), where the Karakoram Highway crosses from Pakistan, and (ii) Zhangmu (in Tibet), where the Friendship Highway crosses from Tibet into Nepal. The three open ports in Tibet - Zhangmu, Nielamu, and Xigaze all lie on the Friendship Highway between Kathmandu (Nepal) and Lhasa (Tibet), there is only one border-crossing between China and Nepal at Zhangmu. It is reported that this open port also

\footnotetext{
${ }^{9}$ The South Asian Association of Regional Cooperation (SAARC) countries are Bangladesh, Bhutan, India, Maldives, Nepal, Pakistan, and Sri Lanka.
} 
carries transit traffic to and from India. Tibet's cross-border trade amounted to about US\$82 million in 2001 through this point. Zhangmu is also important for tourism, and about 300,000 tourists have visited Tibet through the Zhangmu border in 2001.

Map 1. Indo-China Trade Route

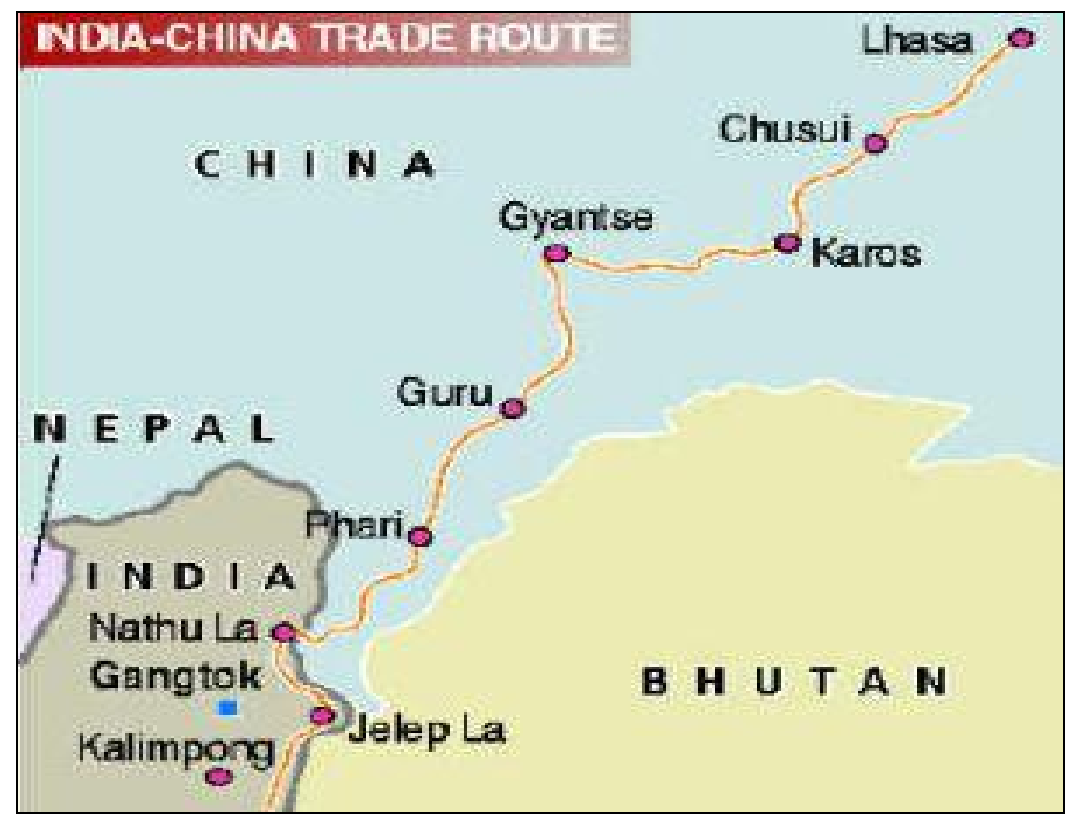

Source: Chaudhuri, 2003.

In 2003, India has signed an agreement with China for reopening a border crossing and trade point at Nathu La in Sikkim, which could be the first direct border trading point between Northeastern India and Southwestern China. ${ }^{11}$ In view of the agreement, the two sides have designated Tsomgo (Changgu) in Sikkim and Renqinggang in the Tibet as the venue for the border trade market. The two sides agree to use Nathu La pass as the transit point for persons, transport vehicles, and commodities engaged in border trade. Each side will establish check points at appropriate locations to monitor and manage their movement through the Nathu La pass.

\footnotetext{
${ }^{11}$ During the visit of India's Prime Minister to China in June 2003, China and India signed an agreement that commits both sides to trade through Nathu La in Northeast Sikkim (India) and Yardong in Tibet (China). This border crossing point was closed after the India-China War in 1962. Today, there are good road links to Kathmandu (700 km), Kolkata (800 km), Dhaka (1000 km) and Lasha (450 km).
} 
The Nathu La pass is located $54 \mathrm{~km}$ from Gangtok, the capital of Sikkim in India. This is considered to be the shortest trade route to Lhasa, which is $525 \mathrm{~km}$ from the Nathu La pass. The Tibetan town of Yatung is 52 kms. from Nathu La. The route connects Phari, Guru, Gyantse, Karos, Chusiu, and Lhasa on the Chinese side of the trading points (Map 1). Like other border trade agreements signed by the Government of India with its neighbouring countries, this agreement is also likely to have a much larger scope in terms of the coverage of regions and goods and services because of a greater accessibility to and more developed physical and institutional infrastructure in and around the trading points. Further, this trade route was a very active means of economic exchange before it was closed in the mid-1960s.

Institutions like banking, post offices, and custom offices were all set up and remained functional for many years. Since accessibility to Tibet from mainland China remained very difficult, the Nathu La trade route was of crucial importance.

The Nathu La border crossing is unlikely ever to constitute a major trade route between China and India. The distances to other countries are too great, and the regular winter closures and frequent temporary closure at other times rule out the Nathu La border as a major cross-border trade route between China and India. This border crossing would be very suitable for local trade and tourism. The big opportunities for the Northeast India also lie in developing trade routes from Arunachal Pradesh/Assam/Manipur to Myanmar and Yunnan Province in China. A very recent development is road linking China, Myanmar and India has been opened to traffic. The road section from Pingyuan to Nabang in Injiang County, Yunnan Province which lies on the border with Myanmar was opened to traffic on 9 April 2005. After the opening to traffic of this road, the travel distance from Kunming, Yunnan Province, via Myitkyina in Myanmar, to Ledo in India is about 1,200 km. At present, freight transport between Yunnan and India has to follow a roundabout route from Kunming to Zhanjiang port in Guangdong Province then to be loaded onto ships bound for India via Malacca Straits - a total of 6,000 km. This road will also facilitate freight transport from Yunnan to Europe and Africa via seaports in Myanmar and India. Strengthening cooperation among China, India, and Myanmar would facilitate direct (and non-stop) railway/road/air linkage between China and India. Here, China, India, and Myanmar can learn from the experiences of North American Free Trade Agreement (NAFTA). In view of the regional geo-political setting, cross-border trade between China and India will always be beneficial to the local population. However, its contribution largely depends on two factors: the 
export potential and the existence of suitable conditions for the growth of cities. Without trade, a border area risks becoming a closed national economy.

\section{Complementarities between NEI and SWC}

Trade flows between regions are determined by the spatial distribution of economic activity and their combined strengths. NEI and SWC are strategically well located, serving a hinterland which shares $45 \%$ of world population. ${ }^{12}$

Table 7. Combined Strengths of NEI and SWC

\begin{tabular}{|c|c|c|}
\hline Particulars & $\mathrm{NEI}+\mathrm{SWC}^{\mathrm{a}}$ & $\begin{array}{c}\text { Share in India }{ }^{b} \\
\text { China }^{b}\end{array}$ \\
\hline Population (2001) & 163.67 million & $7 \%$ \\
\hline Area (2001) & $1,846,196 \mathrm{sq} \mathrm{km}$ & $15 \%$ \\
\hline Population Density (2001) & 88.65 per sq. $\mathrm{km}$ & \\
\hline Ave. per capita GDP (2001) & US\$475 & \\
\hline Ave. share in GDP (2001) & & $18 \%$ \\
\hline Natural gas reserves (2001) & $200 \mathrm{bcm}$ & na \\
\hline Oil reserves (2001) & 1.50 billion tons & na \\
\hline Coal reserves (2001) & 900 million tons & na \\
\hline Hydropower reserves (2001) & $300 \mathrm{GW}$ & $65 \%$ \\
\hline Tourist arrivals (2001) & 30 million & $\mathrm{Na}$ \\
\hline $\begin{array}{l}\text { Competitive advantage in } \\
\text { industrial products }\end{array}$ & \multicolumn{2}{|c|}{$\begin{array}{l}\text { Agro and food based products, plantation products, } \\
\text { chemicals, machinery, building materials }\end{array}$} \\
\hline
\end{tabular}

a. Data for China is for the year 2000 while that for India is 2001. NE India considers states which are mentioned in table 1 and southwest China provinces are Yunnan and Tibet.

b. Rounded off, the term "na" stands for not available.

Source: Authors own calculation based on various secondary sources.

Combined strengths of NEI and SWC are phenomenal: $7 \%$ of the population reside in $15 \%$ of the territory, and contribute 18\% of GDP (see Tables 7 and 8). States/provinces in this area are lying in a level of economic activity where income disparity among members is marginal. This is an ideal situation where closer economic cooperation between China and India will help utilize the

${ }^{12}$ The location of State of Assam for instance was first recognized by the India's first Prime Minister Jawarlal Nehru. Mr. Nehru visited Assam in December 1945 and, summing up his impressions in Kolkata, said, "Assam has the look of great reserves of strength and potential power.... I have no doubt that great highways by road, air and rail will go across her connecting China with India, and ultimately connecting East Asia with Europe. Assam will then no longer be an isolated far away province but an important link between the East and West” (Singh, 1987). 
area's vast natural agricultural and other resources for the creation of wealth, leading to improvements in the quality of life of the people. However, potential environment impacts that may be caused by extraction of natural mineral resources in these regions should be taken into consideration during the formulation of projects in this area

Trade is the easiest instrument for promoting cooperation among countries in a region or subregion. But the interdependence of trade and investment is apparent from the simple facts: that without adequate transportation facilities, maximization of mutually beneficial trade opportunities cannot take place; that development of multimodal transportation requires large-scale investments; and that economies of scale may dictate that such investments should be crossborder investments. Such investments, moreover, can benefit the poorest people in the most remote locations of Northeastern India and Southwestern China.

Roads, railways, and inland waterways are the dominant modes for trade between China and India, roads being the most important. To minimize environmental pollution, it is advisable to lay emphasis on rail and inland water transport. Currently, trans-border rail links between China and India do not exist. With such great rivers as the Ganga, Brahmaputra, and Mekong, inland water transportation has immense potentials for trade ties between China and India.

Table 8. Combined Advantages of NEI and SWC

- Strategic location

- Considerable penetration of railways, roadways, waterways, ports, and shipping

- Untapped and underutilized natural energy

- Vast reserve of natural resources

- Human resources

- A 400 million strong market

- Versatile tourism market

- Linked with India-Myanmar-Thailand Trilateral Highway, Asian Highway and Trans-Asian Railway networks

In the development of hydropower, profitable commercial investment and extensive markets will depend on cooperation between China and India and also neighbouring countries. Only about 3,500 MW of the hydropower potential of the Ganga and Brahmaputra basin have been or are 
being tapped presently, while the estimated total stands at 90,000 MW approximately. The Ganga basin accounts for $40 \%$ of this hydropower, and the Brahmaputra basin for $57 \%$. With $37 \%$ of this potential, northeast India remains the largest reservoir of hydropower in the eastern South Asia subregion, while Bhutan commands 23\%, Nepal 28\% and north India's Ganga catchment area only $12 \%$. Much of India's unutilized hydropower potential is located in the Brahmaputra basin. In India's Arunachal Pradesh, which has 39\% of India's power potential, only $2 \%$ of this reserve is currently being energized. Hydropower in India's northeast can be marketed in the southwest provinces of Bangladesh, China and Myanmar. Massive investments are required for the development of the hydropower resources of the Ganga-Brahmaputra basin, and can be productive with enhanced cooperation between China and India. This can thus result in an integration of the power transmission and distribution networks of Bangladesh, Bhutan, China, India, Myanmar, and Nepal.

Coordinated planning of hydropower investments and power transmission networks entails decision making on an exceedingly complex matter. Smaller countries usually have concerns about being marginalized by big neighbours like China or India. But complexity decreases with strong administrative political to facilitate trade and investment between China and India. Some of the requisite official decisions have to be carried out multilaterally and others bilaterally. Moreover, administrative matters and political will have to be directed toward an enhancing partnership between the public and private sectors of China, India, and Myanmar.

Attracting investments for mega projects in highway or hydropower development in India's northeast may require the combined efforts of public and private agencies in the countries concerned. While ADB has launched initiatives for the development of South and Southeast Asia under SASEC and the Greater Mekong Region (GMS) ${ }^{13}$ programs, respectively, much more needs to be done by China and India to draw investments from Japan, Europe, and North America for promotion of trade and investment between provinces in India's northeast and China's southwest. Many other areas in the world are also competing for investments. Therefore, publicprivate agencies in China and India must cooperate to collect/disseminate information and adopt a strategy to secure foreign investments. Attempts should be made to strengthen networking among chambers of commerce in India's Northeast and China's Southwest, and among respective government agencies, in such a way that promotional activities (e.g. in tourism) can avoid wasteful competition among various subregional cooperation blocs in the region and multiply

${ }^{13}$ http://www.adb.org/Documents/CSPs/GMS/2004/RCSP.asp 
mutual benefits. Such networking can ensure that investment by India in China and vice versa will be so designed and located to maximize impact upon the entire area and enhance growth by trade and employment generation.

A major barrier to expanding India's trade with bordering countries is the lack of adequate transport network. Cross-border infrastructure development can create a sound environment in geographically proximate or integrated areas for promoting prosperity of trade and investment. In China and India, a majority of the poor lives in the remote and/or isolated areas, especially in the cross-border regions. These areas urgently need to set up linkages with the outside world, through highway, railway, and telecommunication to take advantage of their rich resources or cheap labour. Cross-border infrastructure programs could make use of complementarities and economies of scale in these geographically contiguous areas. The establishment of physical linkage through transportation and telecommunications would reduce the cost for factor mobility and increase trade and investment.

The development of adequate and good quality transport infrastructure such as road, air, shipping and rail networks in these regions will pave the way toward promoting international trade between the India and her immediate bordering countries and regions. Improving transport infrastructure can generate economic activities in the Northeastern States of India - i.e., increased international trade - and will, in the process, spur development and improve the quality of life. Better transport facilities are vital in reducing inter- and intra- country inequality. To achieve substantial progress through international trade and economic cooperation, priority should be given to the development of infrastructure facilities (Ghosh and De, 2000; De and Ghosh, 2001 and 2004; De, 2002). Added to this, complementary policy reforms, accompanied by improved procedural and operational efficiency in the transport sector, are essential for supporting trade liberalization. In Asia, Jordan, Iran, and Kazakhstan are examples of countries that have actually invested in new highway and railway construction in order to maximise earnings from transit traffic. The highly successful Greater Mekong Subregional cooperation project, being assisted by the $\mathrm{ADB}$, seeks to promote the three Cs - connectivity, cooperation and competitiveness. One of its two east-west road corridors will soon connect the Andaman Sea (the Myanmar coast) through Thailand and Laos with the South China Sea (at Danang in Vietnam). Therefore, time is ripe for China and India to cooperate each other by sharing each other's strengths in social and economic infrastructure, resulting which economies of both the countries, particularly regions that are relatively poor, will gain appreciably. 
Finally, public and private sector agencies in China and India must pool their resources to launch a comprehensive and systematic entrepreneurship development program, particularly in India's northeast and China's southwest. New entrepreneurs, even though working on a small scale, often come up with significant innovations (as in the United States). If such entrepreneurs can hopefully provide original products in the sectors of information technology, biotechnology, or solar/wind energy, these will substantially contribute to poverty reduction, growth, investment and trade in China and India, particularly in Northeastern India and Southwestern China. Cooperative development in this region can also gather forces to counteract some of the adverse effects of globalization by reducing the economic disparity between high and low income countries, or, what is far more practicable, by using China-India solidarity to cope with this richpoor disparity.

Table 9. Complementarities between NEI and SWC

\begin{tabular}{|l|l|}
\hline \multicolumn{1}{|c|}{ NEI's Strengths } & \multicolumn{1}{|c|}{ SWC's Strengths } \\
\hline $\begin{array}{l}\text { Stable railways, waterways, roadways, ports } \\
\text { and shipping networks }\end{array}$ & Stable roadways and airways network \\
\hline $\begin{array}{l}\text { Bordering mainland Bangladesh, India, and } \\
\text { Myanmar }\end{array}$ & $\begin{array}{l}\text { Bordering mainland China and some ASEAN } \\
\text { members }\end{array}$ \\
\hline Large pool of English-speaking population & Rising English-speaking population \\
\hline Developed IT software & $\begin{array}{l}\text { Developed IT Hardware and electronic } \\
\text { equipment }\end{array}$ \\
\hline Underutilized capacity in construction & Huge potential demand for infrastructure \\
\hline Presence of private capital & Scopes for private enterprises \\
\hline
\end{tabular}

Geographical contiguity can facilitate the development of vast natural endowments (natural gas, coal, and hydropower reserves), provided a conducive environment is created through close bilateral cooperation. As we have seen in previous section, there exist considerable complementarities in trading infrastructure and related facilities between India and China. Table 9 briefly captures these complementarities. Therefore, border trade potential between China and India can be realized by creating proper trade and communication facilities at the border points. While cross-border investment does not exist at present, strengthening existing communication facilities between NEI and SWC will generate cross-border investments. Closer cooperation between China and India may help in developing this vast and unexploited potential of crossborder cooperation for mutual benefit. Such cooperation will contribute in fostering publicprivate partnership in enriching the economic life of the regions concerned. This will, moreover, enable both governments to expand the necessary infrastructure facilities and to adopt favourable 
policies, which will boost the competitiveness of China and India in the global market. There are some positive indications of joint ventures between Indian and Chinese oil companies in biding energy sector projects in third country. For instance, while ONGC Videsh Ltd. (an Indian Fortune 500 public sector company) partners Chinese firms in Sudan, Ivory Coast, and Russia.

Although there are some differences between NEI and SWC because of different cultural backgrounds and history, these differences can ignite great possibilities for the two regions to complement their economic efforts. For example, their unique natural resources and culture will attract tourists, and the mineral resources from diverse geological structures will enable the two regions to complement their demands. The different techniques in the fields of agriculture, and industry, especially computer hardware and software, will provide a large scope for technological exchange and transfer.

\subsection{Subregional Initiatives: SASEC Program}

There exists a subregional initiative, called, the South Asia Growth Quadrangle (SAGQ) which was constituted in by the foreign ministers of Bangladesh, Bhutan, India and Nepal (BBIN) during the Ninth Summit of SAARC on May 1997 in Male. The South Asia Subregional Economic Cooperation (SASEC) of ADB, as aimed to identify projects which would support development of SAGQ, endorsed by SAARC in 1997. The membership of SASEC includes Bangladesh, Bhutan, India, and Nepal.

The successful implementation of the SASEC program will enhance cooperation between TAR and NER in the transport infrastructure area. According to the concept paper ${ }^{14}$ for SASEC's transport-related activities, the program envisages: “An investment program for the subregion could potentially include an economic corridor around the Bay of Bengal, linking ports from Chittagong to Dhaka, Mongla, Calcutta, and Haldia. It could also include a transport grid of eastwest railroads and highways linking the eastern Indian hill states with West Bengal through Bangladesh, as well as north-south transport corridors linking Nepal, Bhutan, and the hill states of eastern India to ports on the Bay of Bengal. This grid could be connected to the rest of India at Calcutta through India's top priority Golden Quadrilateral project of superhighways joining Delhi, Bombay, Chennai, and Calcutta.”

\footnotetext{
${ }^{14}$ http://www.adb.org/documents/events/2000/private_sector_forum/calcutta-transport.pdf
} 
China and India are both great nations that in the past created splendid civilizations in world history. Currently, both the countries are faced with high pressures of population growth, poverty and income disparity. A strong economy can be developed by learning from each other's experiences and complementarities. Some of the areas where eastern and northeast India and southwest China can cooperate include tourism, education, rail transport, ports and shipping, road transport, media and entertainment, plantation sector, and agro and food processing. Southwest China can contribute to northeast India's development in several areas. These include infrastructure, particularly roads and airways, logistics, industrial parks, tourism, and food processing. Northeast India can also contribute to southwest China's development in education, IT services, telecommunication, housing and real estate. Continuous cooperation between China and India will transform these complementarities for the benefit of the regions.

\section{Concluding Remarks}

Economies, societies, regions, and nations around the world are fast becoming integrated among themselves and into the world economy, especially during the last the decade in an unprecedented way. Not only commodities but also factors of production and services are becoming more and more mobile internationally. In one sense, if an economy or a region within an economy fails to integrate itself into the changing world or fails to maintain a competitive and decent economic environment, its most valuable human resources will eventually move out of the region, thereby making it a loser in today's world. Globalization means increasing access to world resources. It also means "competition" in a world economy and survival of the fittest: whether an individual, firm, region, or nation.

Integration will bring reduced transaction costs; greater productive infrastructure services; lower trade barriers; faster communication of ideas, goods and services, rising capital flows; It requires a strong political will not only at the national level but also at the regional level. Hence, "integration" is the other name of "globalization". Cooperation in trade, tourism, and industries between China and India, is very vital. Such cooperation can carry forward certain initiatives about China-India relations, which have already been launched. 
Since both China and India are focused on achieving the status of developed countries through an appropriate set of policies and actions, narrow political considerations need not inhibit the spirit of growing cooperation. Given India's gradual emergence as a knowledge-based economy, and of China as a manufacturing-based economy, and the existence of diversities as well as complementarities, NEI and SWC will certainly benefit from closer economic cooperation. However, looking at the overall geopolitical settings, both countries are likely to take cautious steps in facilitating cross-border interaction. To move in this direction, apart from encouraging regular exchanges between cultural, business and academic institutions of the two countries, the governments may together conduct a detailed policy planning study to plan a strategy and a road map of gradually expanding cooperation.

The lack of adequate transport infrastructure is one of the major barriers to expanding India's trade with the bordering countries. One of the key constraints for developing transport infrastructure is lack of adequate financial resources. The central and local governments and multilateral organizations have an important role to play in cross-border infrastructure development. The available sources of fund include the central government, local government, local capital market, and private institutions, international market, and multilateral organizations. As most infrastructure projects in NEI will not generate high profit in the short term, it is difficult to attract private sector or raise money from local capital markets. Local governments in these regions do not have adequate financial resources. However, public-private partnerships, particularly involving local governments should be encouraged. The involvement of local governments will ensure ownership and guarantee while that of the private sector will provide technical expertise and efficiency as well as financing. Finally, an advocacy of enhanced cooperation between China and India does not imply any restriction upon existing subregional cooperation in the larger surrounding area, i.e., among countries belonging to SAARC, SASEC and BIMST-EC. Cooperation between China and India (in matters of trade and/or investment) can sustain themselves regardless of operation of other multi-country cooperation initiatives. Geographical contiguity buttresses China-India cooperation. Other subregional cooperation initiatives should not be perceived as constraints in developing the potential cooperation between China and India. Moreover, the development of cooperation between China and India can enhance cooperation of these two countries with various countries in Southeast Asia and East Asia.

In view of this, the environment for greater integration between China and India is better than ever while the opportunity cost of non-integration continues to increase. This is the right time for 
China and India to intensify cooperation between SWC and NEI. Initiatives must be taken for closer economic exchanges between China and India for greater promotion of trade and investment between NEI and SWC. Being members of the WTO, China and India can benefit from a globalizing market economy. Finally, this cooperation will improve the quality of life of the common people in both China and India. 


\section{References}

Asian Development Bank (ADB). 2002. The 2020 Project: Policy Support in the People's Republic of China Manila.

Baruah, Srinath. 2000. "Certain Observations on Informal Trade with Neighboring Countries and Economic Prospects of the North Eastern Region”. In Border Trade: North East India and Neighboring Countries. Akansha Publishing House, New Delhi.

Chaudhuri, Kalyan. 2003. Routes of Promise, Frontline. Chennai, July 5.

Das, Gurudas. 2000. “Trade between the North Eastern Region and Neighboring Countries: Structures and Implications for Development”. Border Trade: North East India and Neighboring Countries, op.cit.

De, P. 2002. Kolkata to Kunming Initiative (K2K): An Approach Paper, Presentation made at the Workshop on Sino - India Bilateral Cooperation held at Kunming, China, organized by Yunnan Development Research Center, Kunming, November 19-21.

De, P. and B. Ghosh. 2001. Transport Infrastructure and Economic Performance of Bangladesh and Indian Bordering States. BIISS Journal, Vol. 22, No. 4.

De, P. and B. Ghosh. 2004. Deepening Cooperation in the BIMST-EC: A Case for Transport Integration. BIISS Journal, Vol. 25, No. 2.

Ghosh, B. and P. De. 2000. Infrastructure, Economic Growth and Trade in SAARC, BIISS Journal, Vol. 21, No.2.

Government of India. 1997. High Level Commission Report to the Prime Minister: Transforming the Northeast: Tackling Backlogs in Basic Minimum Services and Infrastructural Needs. New Delhi.

Government of India, 2005, Report of the India-China Joint Study Group on Comprehensive Trade and Economic Cooperation, Ministry of External Affairs, New Delhi. Available at www.meaindia.nic.in

Ray, J. K. and P. De. 2003. Promotion of Trade and Investment in Eastern South Asia Subregion. New Delhi: Bookwell.

Ray, J. K and P. De. 2005. India and China in the Era of Globalisation: Essays on Economic Cooperation, New Delhi: Bookwell.

Singh, B. P. 1987. The Problem of Change: A Study of North-East India. New Delhi: Oxford University Press.

Verghese, B. G. 1997. India's Northeast Resurgent: Ethnicity, Insurgency, Governance, Development. New Delhi: Konark Publishers. 


\section{CESifo Working Paper Series}

(for full list see www.cesifo-group.de)

1441 John Whalley, Globalization and Values, April 2005

1442 Denise L. Mauzerall, Babar Sultan, Namsoug Kim and David F. Bradford, Charging $\mathrm{NO}_{x}$ Emitters for Health Damages: An Exploratory Analysis, April 2005

1443 Britta Hamburg, Mathias Hoffmann and Joachim Keller, Consumption, Wealth and Business Cycles in Germany, April 2005

1444 Kohei Daido and Hideshi Itoh, The Pygmalion Effect: An Agency Model with Reference Dependent Preferences, April 2005

1445 John Whalley, Rationality, Irrationality and Economic Cognition, April 2005

1446 Henning Bohn, The Sustainability of Fiscal Policy in the United States, April 2005

1447 Torben M. Andersen, Is there a Role for an Active Fiscal Stabilization Policy? April 2005

1448 Hans Gersbach and Hans Haller, Bargaining Power and Equilibrium Consumption, April 2005

1449 Jerome L. Stein, The Transition Economies: A NATREX Evaluation of Research, April 2005

1450 Raymond Riezman, John Whalley and Shunming Zhang, Metrics Capturing the Degree to which Individual Economies are Globalized, April 2005

1451 Romain Ranciere, Aaron Tornell and Frank Westermann, Systemic Crises and Growth, April 2005

1452 Plutarchos Sakellaris and Focco W. Vijselaar, Capital Quality Improvement and the Sources of Growth in the Euro Area, April 2005

1453 Kevin Milligan and Michael Smart, Regional Grants as Pork Barrel Politics, April 2005

1454 Panu Poutvaara and Andreas Wagener, To Draft or not to Draft? Efficiency, Generational Incidence, and Political Economy of Military Conscription, April 2005

1455 Maurice Kugler and Hillel Rapoport, Skilled Emigration, Business Networks and Foreign Direct Investment, April 2005

1456 Yin-Wong Cheung and Eiji Fujii, Cross-Country Relative Price Volatility: Effects of Market Structure, April 2005 
1457 Margarita Katsimi and Thomas Moutos, Inequality and Relative Reliance on Tariffs: Theory and Evidence, April 2005

1458 Monika Bütler, Olivia Huguenin and Federica Teppa, Why Forcing People to Save for Retirement may Backfire, April 2005

1459 Jos Jansen, The Effects of Disclosure Regulation of an Innovative Firm, April 2005

1460 Helge Bennmarker, Kenneth Carling and Bertil Holmlund, Do Benefit Hikes Damage Job Finding? Evidence from Swedish Unemployment Insurance Reforms, May 2005

1461 Steffen Huck, Kai A. Konrad and Wieland Müller, Merger without Cost Advantages, May 2005

1462 Louis Eeckhoudt and Harris Schlesinger, Putting Risk in its Proper Place, May 2005

1463 Hui Huang, John Whalley and Shunming Zhang, Trade Liberalization in a Joint Spatial Inter-Temporal Trade Model, May 2005

1464 Mikael Priks, Optimal Rent Extraction in Pre-Industrial England and France - Default Risk and Monitoring Costs, May 2005

1465 François Ortalo-Magné and Sven Rady, Heterogeneity within Communities: A Stochastic Model with Tenure Choice, May 2005

1466 Jukka Pirttilä and Sanna Tenhunen, Pawns and Queens Revisited: Public Provision of Private Goods when Individuals make Mistakes, May 2005

1467 Ernst Fehr, Susanne Kremhelmer and Klaus M. Schmidt, Fairness and the Optimal Allocation of Ownership Rights, May 2005

1468 Bruno S. Frey, Knight Fever - Towards an Economics of Awards, May 2005

1469 Torberg Falch and Marte Rønning, The Influence of Student Achievement on Teacher Turnover, May 2005

1470 John Komlos and Peter Salamon, The Poverty of Growth with Interdependent Utility Functions, May 2005

1471 Hui Huang, Yi Wang, Yiming Wang, John Whalley and Shunming Zhang, A Trade Model with an Optimal Exchange Rate Motivated by Current Discussion of a Chinese Renminbi Float, May 2005

1472 Helge Holden, Lars Holden and Steinar Holden, Contract Adjustment under Uncertainty, May 2005

1473 Kai A. Konrad, Silent Interests and All-Pay Auctions, May 2005

1474 Ingo Vogelsang, Electricity Transmission Pricing and Performance-Based Regulation, May 2005 
1475 Spiros Bougheas and Raymond Riezman, Trade and the Distribution of Human Capital, June 2005

1476 Vesa Kanniainen, Seppo Kari and Jouko Ylä-Liedenpohja, The Start-Up and Growth Stages in Enterprise Formation: The "New View" of Dividend Taxation Reconsidered, June 2005

1477 M. Hashem Pesaran, L. Vanessa Smith and Ron P. Smith, What if the UK had Joined the Euro in 1999? An Empirical Evaluation Using a Global VAR, June 2005

1478 Chang Woon Nam and Doina Maria Radulescu, Effects of Corporate Tax Reforms on SMEs' Investment Decisions under the Particular Consideration of Inflation, June 2005

1479 Panos Hatzipanayotou, Sajal Lahiri and Michael S. Michael, Globalization, CrossBorder Pollution and Welfare, June 2005

1480 John Whalley, Pitfalls in the Use of Ad valorem Equivalent Representations of the Trade Impacts of Domestic Policies, June 2005

1481 Edward B. Barbier and Michael Rauscher, Trade and Development in a Labor Surplus Economy, June 2005

1482 Harrie A. A. Verbon and Cees A. Withagen, Tradable Emission Permits in a Federal System, June 2005

1483 Hendrik Hakenes and Andreas Irmen, On the Long-Run Evolution of Technological Knowledge, June 2005

1484 Nicolas Schmitt and Antoine Soubeyran, A Simple Model of Brain Circulation, June 2005

1485 Carsten Hefeker, Uncertainty, Wage Setting and Decision Making in a Monetary Union, June 2005

1486 Ondřej Schneider and Jan Zápal, Fiscal Policy in New EU Member States - Go East, Prudent Man!, June 2005

1487 Christian Schultz, Virtual Capacity and Competition, June 2005

1488 Yvan Lengwiler and Elmar Wolfstetter, Bid Rigging - An Analysis of Corruption in Auctions, June 2005

1489 Johannes Becker and Clemens Fuest, Does Germany Collect Revenue from Taxing Capital Income?, June 2005

1490 Axel Dreher and Panu Poutvaara, Student Flows and Migration: An Empirical Analysis, June 2005

1491 Bernd Huber and Marco Runkel, Interregional Redistribution and Budget Institutions under Asymmetric Information, June 2005 
1492 Guido Tabellini, Culture and Institutions: Economic Development in the Regions of Europe, July 2005

1493 Kurt R. Brekke and Michael Kuhn, Direct to Consumer Advertising in Pharmaceutical Markets, July 2005

1494 Martín Gonzalez-Eiras and Dirk Niepelt, Sustaining Social Security, July 2005

1495 Alfons J. Weichenrieder, (Why) Do we need Corporate Taxation?, July 2005

1496 Paolo M. Panteghini, S-Based Taxation under Default Risk, July 2005

1497 Panos Hatzipanayotou and Michael S. Michael, Migration, Tied Foreign Aid and the Welfare State, July 2005

1498 Agata Antkiewicz and John Whalley, BRICSAM and the Non-WTO, July 2005

1499 Petr Hedbávný, Ondřej Schneider and Jan Zápal, A Fiscal Rule that has Teeth: A Suggestion for a 'Fiscal Sustainability Council' underpinned by the Financial Markets, July 2005

1500 J. Atsu Amegashie and Marco Runkel, Sabotaging Potential Rivals, July 2005

1501 Heikki Oksanen, Actuarial Neutrality across Generations Applied to Public Pensions under Population Ageing: Effects on Government Finances and National Saving, July 2005

1502 Xenia Matschke, Costly Revenue-Raising and the Case for Favoring Import-Competing Industries, July 2005

1503 Horst Raff and Nicolas Schmitt, Why Parallel Trade may Raise Producers Profits, July 2005

1504 Alberto Bisin and Piero Gottardi, Efficient Competitive Equilibria with Adverse Selection, July 2005

1505 Peter A. Zadrozny, Necessary and Sufficient Restrictions for Existence of a Unique Fourth Moment of a Univariate GARCH(p,q) Process, July 2005

1506 Rainer Niemann and Corinna Treisch, Group Taxation, Asymmetric Taxation and Cross-Border Investment Incentives in Austria, July 2005

1507 Thomas Christiaans, Thomas Eichner and Ruediger Pethig, Optimal Pest Control in Agriculture, July 2005

1508 Biswa N. Bhattacharyay and Prabir De, Promotion of Trade and Investments between China and India: The Case of Southwest China and East and Northeast India, July 2005 